Reprod. Nutr. Dévelop., 1987, 27 (3), 721-732.

\title{
Effects of food restriction on cortisol, TSH and iodothyronine concentrations in the plasma of the newborn lamb
}

\author{
Chantal WRUTNIAK, G. CABELLO
}

Laboratoire des Maladies Métaboliques, I.N.R.A., Theix, 63122 Ceyrat, France.

Summary. The influence of food restriction, applied from birth to $36 \mathrm{~h}$ post partum, on neonatal thyroid function was studied in newborn Limousin $\times$ Romanov lambs. The control animals $(n=18$ ) had free access to the mother and suckled ad libitum. Restricted lambs $(n=16)$ were removed from the mother and received limited amounts of colostrum in proportion to birth weight ; 8 lambs were supplemented with lactose ( $30 \mathrm{~g} / /$ of colostrum).

Plasma glucose and free fatty acid levels were significantly lower in restricted lambs, whereas urea levels were elevated. Plasma cortisol concentrations in control animals decreased during the period studied, but rose during the first $8 \mathrm{~h}$ of life in restricted lambs. Lactose supplementation only partially restored glucose and urea levels.

Food restriction induced considerable modifications in neonatal thyroid function. The postpartum rise in plasma thyroid-stimulating hormone (TSH), thyroxine (T4) and free T4 levels occurring in control lambs was inhibited in restricted animals. However, the surge in plasma triiodothyronine (T3) levels was not affected, suggesting that this change was not related to physiological neonatal TSH hypersecretion. Thereafter, thyroid hormone concentrations decreased sharply during food restriction, whereas reverse T3 levels remained higher than in the controls. In response to these T4 and T3 deficiencies, plasma TSH levels rose only in lactose-supplemented animals.

In agreement with the significant modifications in the values of the T3/free T4 and reverse T3/free T4 ratios, the abrupt changes in T3 and reverse T3 levels suggest that food restriction affected the peripheral conversion of T4 into T3 and reverse T3.

Twelve hours after the onset of refeeding, plasma T4 and reverse T3 levels were restored, but not the T3 levels ; this agrees with results obtained in other animals.

In conclusion, food restriction strongly affected neonatal thyroid function in lambs in terms of secretion and peripheral T4 conversion.

\section{Introduction.}

Over the last decade it has been emphasized that thyroid function is important to the health of newborns. For instance, lowered plasma thyroid hormone concentrations have been implicated in the respiratory distress syndrome (Redding and Pereira, 1974 ; Cuestas et al., 1976), and disturbances in thyroid function have been associated with the occurrence of disease in newborn calves (Cabello and Michel, 1974 ; Cabello, 1980). Moreover, thyroid hormone affects physiological processes such as thermoregulation (Cabello, 1983 ; Wrutniak, 1985 ; Wrutniak and Cabello, 1986), obtention of passive immunity (Cabello and 
Levieux, 1981 ; Cabello et al., 1983) and intestinal E. coli adhesion (Cabello et al., 1984) which are necessary for the survival of newborn lambs. Therefore, it is evident that we need a better knowledge of the perinatal factors affecting neonatal thyroid function.

In a previous work (Wrutniak, 1985) we obtained some results suggesting that food restriction might affect thyroid hormone levels in newborn lambs. In the present work, we have observed neonatal changes in plasma total and free T4, T3, reverse T3, TSH, cortisol, glucose, urea and free fatty acid levels in control and restricted lambs. The effect of the addition of lactose in the diet of undernourished animals was also studied.

\section{Material and methods.}

Forty-four newborn Limousin $\times$ Romanov lambs were used in this experiment. Three groups were constituted according to birth weight : control lambs ( $n=18$, mean birth weight : $3.57 \pm 0.19 \mathrm{~kg}$ ), restricted lambs $(n=8$, mean birth weight : $3.23 \pm 0.26 \mathrm{~kg}$ ) and restricted lambs supplemented with lactose ( $\mathrm{n}=8$, mean birth weight : $3.30 \pm 0.29 \mathrm{~kg}$ ). The control lambs had free access to the mother and suckled ad libitum. In the two other groups, food restriction was induced from birth to $36 \mathrm{~h}$ post partum as follows : the restricted lambs were removed from the ewes and bottle-fed with small amounts $12.5 \%$ of the birth weight) of the same colostrum at $4,8,12,16,20,24,28$ and $32 \mathrm{~h}$ post partum ; this colostrum was supplemented with $30 \mathrm{~g}$ of lactose/l in the second group of restricted animals. Ad libitum feeding of artificial milk was allowed from $36 \mathrm{~h}$ post partum. Therefore, the experimental period was divided into two parts : food restriction (birth to $36 \mathrm{~h}$ ) and refeeding ( 36 to $48 \mathrm{~h}$ ).

Blood samples from the jugular vein were collected into heparin at birth and at $4,8,16,36$ (food restriction) and 48 (refeeding) $h$ post partum. The plasma was separated by centrifugation within $15 \mathrm{~min}$ and kept frozen at $-20^{\circ} \mathrm{C}$ until analysis. Concentrations of total and free thyroxine (T4), triiodothyronine (T3), reverse $\mathrm{T} 3$ and cortisol were measured by radioimmunoassay as described previously (Cabello and Levieux, 1980 ; Wrutniak and Cabello, 1985 ; Wrutniak et al., 1985). Ovine thyroid-stimulating hormone (TSH) was also measured by radioimmunoassay using a double antibody separation method; reagents (antisera and cold hormone) were supplied by the National Hormone Program (NIADDK, Bethesda). Assay sensitivity was $0.05 \mathrm{ng} / \mathrm{ml}$ and intraassay variation was $8 \%$; all measurements were performed in the same assay. Plasma glucose, urea and free fatty acid levels were measured colorimetrically according to Bergmeyer et al. (1974), Moore and Sax (1965) and Wrutniak and Cabello (1986).

TSH, total and free T4, T3, reverse T3, glucose and urea means were recorded with the SEM. Since cortisol and free fatty acid values did not show a Gaussian distribution, it was necessary to convert them into logarithms; the values are given after decimal reconversion of the mean of the logarithms. The significance of the differences between the groups was tested by Student's t-test; the significance of the changes in a same group was tested by the paired t-test. 

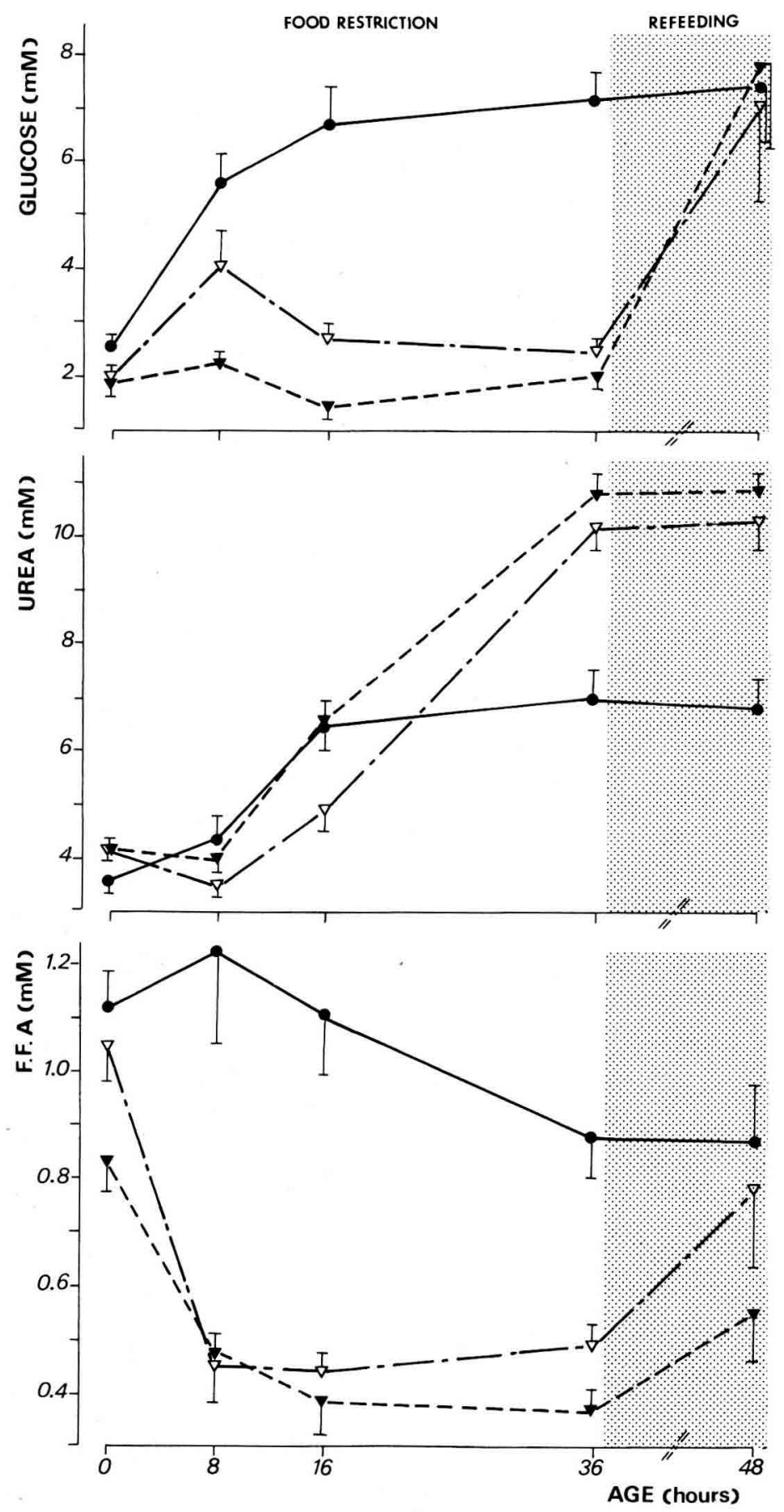

FIG. 1. - Neonatal changes in plasma glucose, urea and free fatty acid levels in control $(\bullet-\bullet)$, restricted $(\nabla-\nabla)$ and restricted lambs supplemented with lactose $(\nabla+-\nabla)$. 


\section{Results.}

1. Changes in plasma glucose, urea, free fatty acid and cortisol levels (figs. 1, 2).

Whereas plasma glucose levels rose sharply during the first $16 \mathrm{~h}$ of life $P<0.001$ ) in control lambs, they decreased between 8 and $16 \mathrm{~h}$ post partum in undernourished animals $(P<0.001)$ and remained very low throughout the period of food restriction ; ad libitum feeding was associated with a complete restoration of these levels. Lactose supplementation induced a transient rise in plasma glucose concentrations from birth to $8 \mathrm{~h}$ post partum ( $\mathrm{P}<0.005$ ) and slightly reduced the severity of the hypoglycemia recorded in restricted lambs at 8, 16 and $36 \mathrm{~h}$ post partum $(\mathrm{P}<0.001, \mathrm{P}<0.01$ and $\mathrm{P}<0.025$ ).

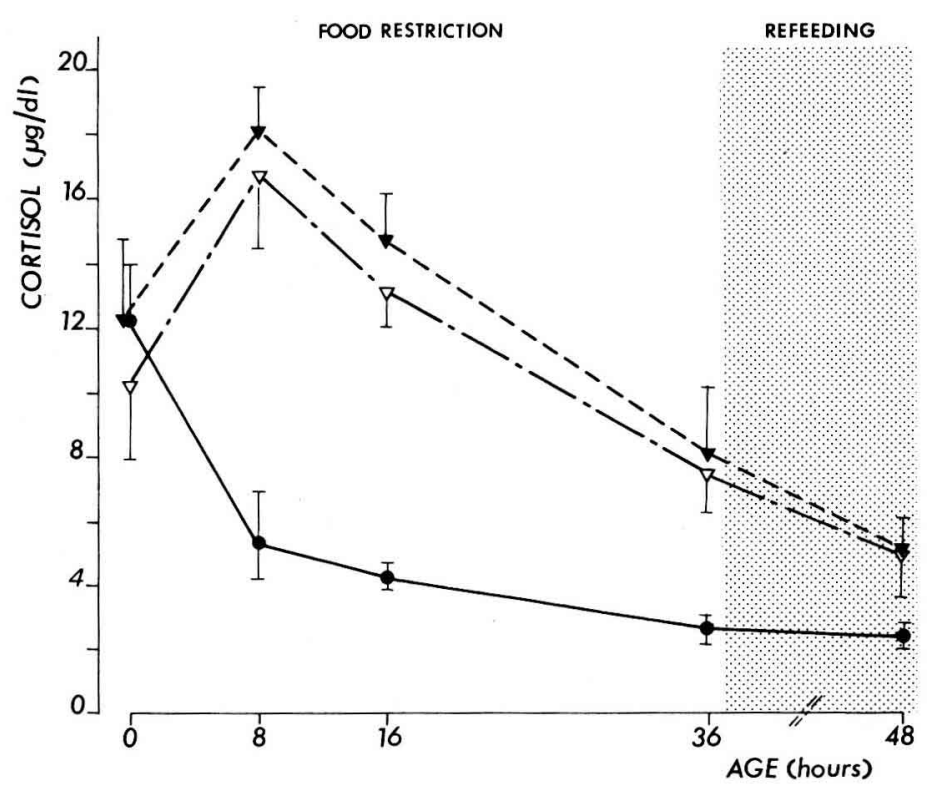

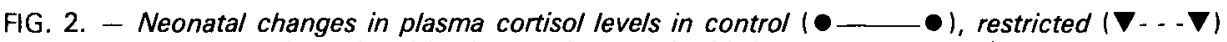
and restricted lambs supplemented with lactose $(\nabla+.-\nabla)$.

In control lambs, plasma urea levels rose during the first $16 \mathrm{~h}$ of life $(P<0.001)$. They increased sharply throughout the period of food restriction in undernourished animals $(P<0.001)$ and did not change $12 \mathrm{~h}$ after the onset of ad libitum feeding. Lactose supplementation slightly reduced the plasma urea concentrations recorded in restricted lambs at 8,16 and $36 \mathrm{~h}$ post partum (P< 0.025 to $P<0.001)$.

Plasma free fatty acid levels progressively decreased from 8 to $36 \mathrm{~h}$ post partum in control lambs $(P<0.05)$. They decreased sharply during the first $8 \mathrm{~h}$ of life in restricted animals $(P<0.001)$ and remained unchanged thereafter. Lactose supplementation did not affect free fatty acid levels at any time during food res- 
triction. However, $12 \mathrm{~h}$ after the onset of ad libitum feeding, these concentrations were only restored in lactose-supplemented lambs.

In control lambs, plasma cortisol levels decreased progressively $(P<0.001)$ throughout the period studied. However, in restricted lambs they rose during the first $8 \mathrm{~h}$ of life and declined thereafter $(P<0.01)$. Therefore, they were higher than in the controls from 8 to $48 \mathrm{~h}$ post partum $(\mathrm{P}<0.005)$. Lactose supplementation did not affect plasma cortisol levels in restricted lambs.

2. Changes in plasma TSH and iodothyronine levels (figs. 3, 4).

Plasma TSH levels were characterized by a high variability in each experimental group. In control lambs they rose significantly during the first $8 \mathrm{~h}$ of life $(P<0.05)$; thereafter they decreased until $36 \mathrm{~h}$ post partum $(\mathrm{P}<0.001)$. No significant changes were observed in restricted animals at any time during the period studied. In lactose-supplemented lambs plasma TSH levels rose between 8 and $16 \mathrm{~h}$ post partum $(\mathrm{P}<0.001)$ and declined thereafter until $48 \mathrm{~h}$ post partum $(P<0.001)$ to reach a value similar to that recorded at birth.

Significant differences were noted between the controls and the two groups of restricted lambs at $8 \mathrm{~h}$ post partum $(\mathrm{P}<0.05)$.

In control lambs, plasma total and free T4 levels rose significantly during the first $8 \mathrm{~h}$ of life and decreased until 16 (total T4; $\mathrm{P}<0.05$ ) or 36 (free T4; $P<0.025) \mathrm{h}$ post partum. Such a postnatal rise did not appear in restricted ani-

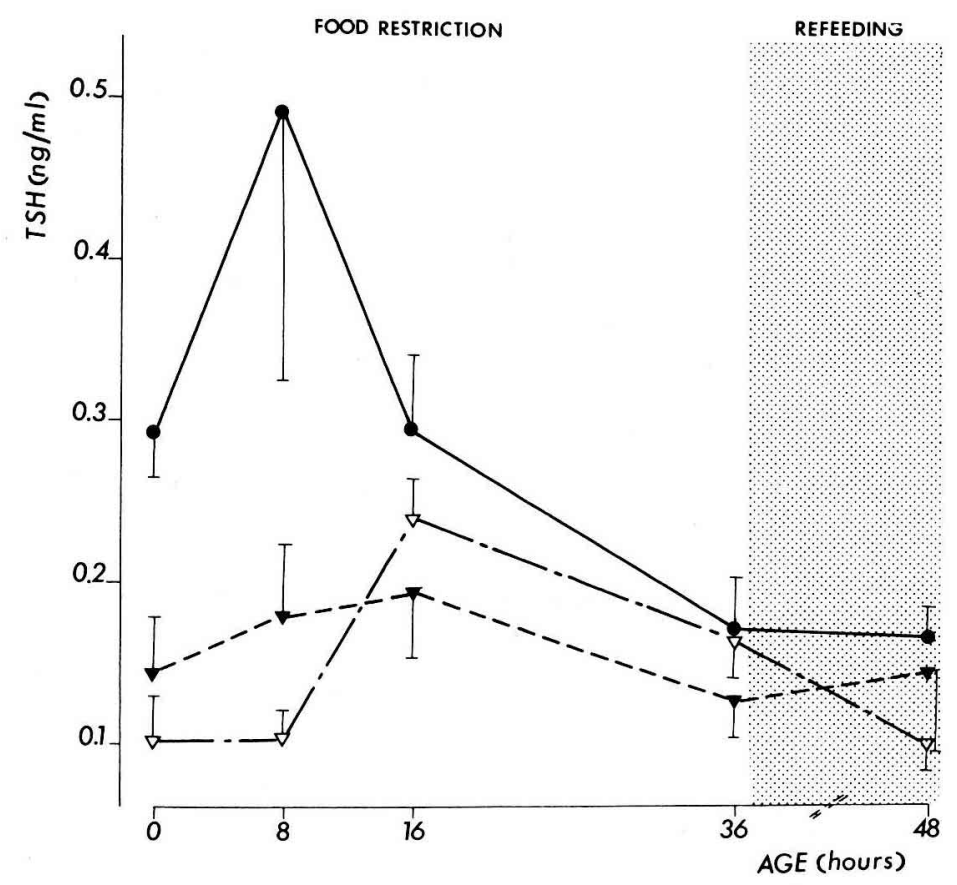

FIG. 3. - Neonatal changes in plasma TSH levels in control $(\bullet-\bullet)$, restricted $\left(\boldsymbol{\nabla}-\boldsymbol{-}_{-}\right)$ and restricted lambs supplemented with lactose $(\nabla+\cdot-\nabla)$. 

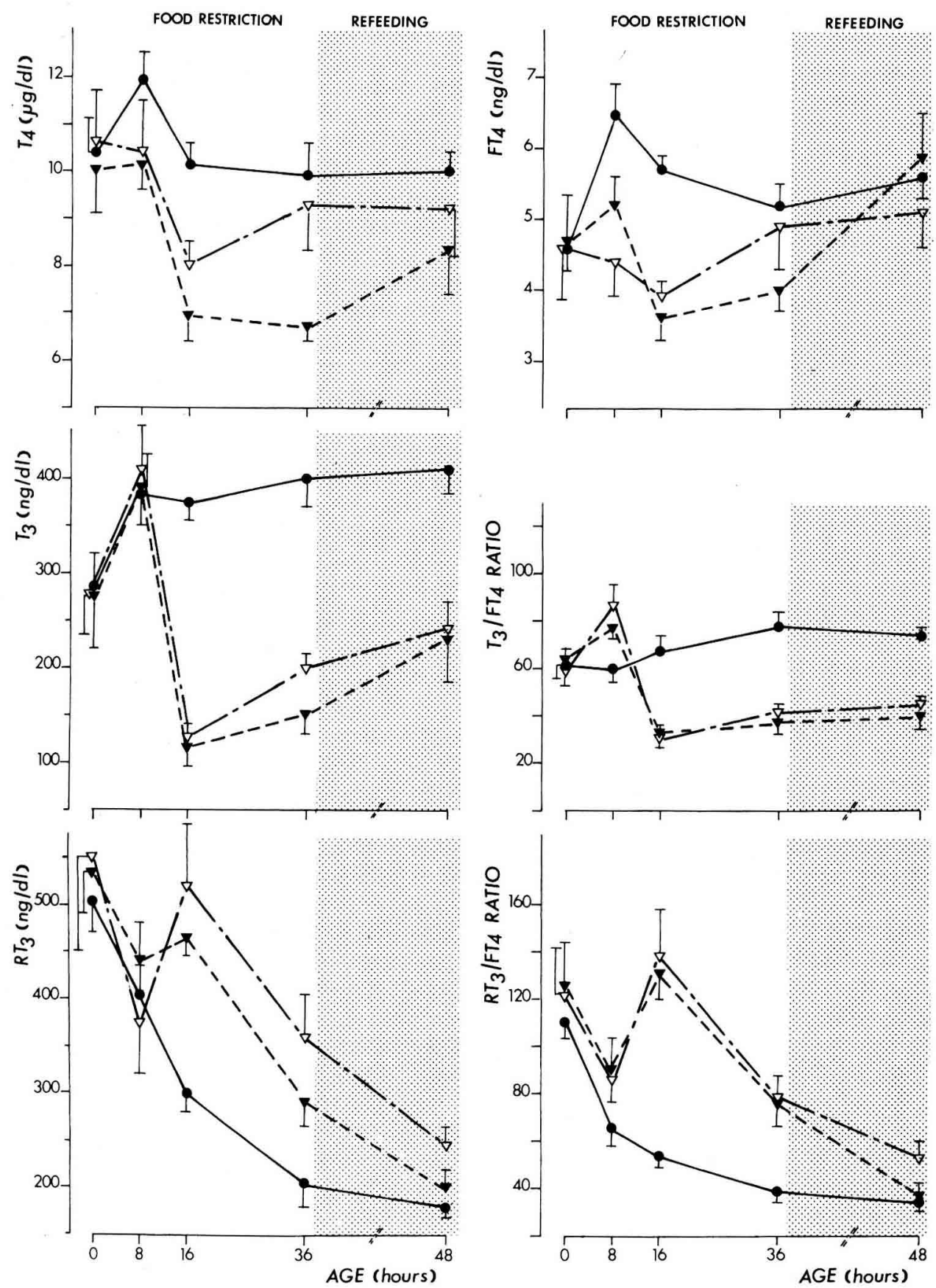

FIG. 4. - Neonatal changes in plasma iodothyronines levels in control ( - - 1 ), restricted $(\boldsymbol{\nabla} \ldots \boldsymbol{\nabla})$ and restricted lambs supplemented with lactose $(\nabla \ldots, \quad \nabla)$. 
mals in which plasma total and free T4 concentrations decreased from 8 to $16 \mathrm{~h}$ $(\mathrm{P}<0.05)$ and remained at low values until $36 \mathrm{~h}$ post partum; they were restored $12 \mathrm{~h}$ after ad libitum feeding. Lactose supplementation reduced the drop in total and free T4 levels; therefore total T4 concentrations were significantly higher $36 \mathrm{~h}$ after birth $(\mathrm{P}<0.05)$ than in restricted lambs.

In both groups plasma T3 levels rose during the first $8 \mathrm{~h}$ of life $(P<0.05)$. However, whereas they remained unchanged in control lambs, they decreased sharply in restricted animals until $16 \mathrm{~h}(\mathrm{P}<0.001)$ and rose slightly thereafter $(\mathrm{P}<0.01)$; they were not restored $12 \mathrm{~h}$ after the onset of ad libitum feeding. Lactose supplementation did not affect plasma T3 levels in undernourished lambs. The changes in the value of the T3/free T4 ratio paralleled those of T3 concentrations.

As did the values of the reverse $\mathrm{T} 3 /$ free $\mathrm{T} 4$ ratio, plasma reverse $\mathrm{T} 3$ levels decreased progressively $(P<0.001)$ throughout the experimental period in control lambs. In restricted animals plasma reverse T3 concentrations did not significantly change during the first $16 \mathrm{~h}$ of life and decreased until $48 \mathrm{~h}$. The values of the reverse $T 3 /$ free $T 4$ ratio rose sharply from 8 to $16 \mathrm{~h}$ after birth $(P<0.05)$ and decreased thereafter $(P<0.001)$. Lactose supplementation did not affect the changes in plasma reverse $T 3$ concentrations or the values of the reverse $T 3 /$ free $\mathrm{T} 4$ ratio in restricted lambs.

\section{Discussion.}

Milk ingestion of suckling lambs has been estimated at $40 \%$ of the birth weight during the first $48 \mathrm{~h}$ of life (Shubber et al., 1979). Therefore, this spontaneous ingestion is much greater than the quantity of colostrum given to lambs removed from the mother ( $20 \%$ of the birth weight). Moreover, in addition to this restriction, the lambs in the present study were totally fasted during the first $4 \mathrm{~h}$ of life, and the interval between each feeding was $4 \mathrm{~h}$. In comparison, lambs reared with the mother suckle spontaneously since the first $30 \mathrm{~min}$ of life and many times per hour during early neonatal life. Therefore, strong modifications of plasma glucose, urea and free fatty acid levels might be expected.

\section{Food restriction.}

a) Changes in plasma glucose, urea, free fatty acid and cortisol levels. - In control lambs, suckling was associated with a sharp increase in glycemia, as observed by Mellor and Pearson (1977). As expected, plasma glucose levels were very low in restricted animals ; a decrease was even observed between 8 and $16 \mathrm{~h}$ post partum. Lactose supplementation only partially increased glycemia and particularly at $4 \mathrm{~h}$ after the first feeding.

Uremia rose in both groups, but this increase was shorter and weaker in suckling lambs. These changes in suckling lambs probably reflect a high protein intake due to colostrum ingestion. In restricted lambs, the sharp rise in urea levels might be due to increased utilization of amino acids for neoglucogenesis in view of the important hypoglycemia ; such a regulation occurs since fetal life (Girard et 
al., 1979). In agreement with this explanation, lactose supplementation significantly reduced hyperuremia and hypoglycemia.

Neonatal food restriction was associated with a sharp decrease in plasma free fatty acid levels, probably due to a reduction in the amount of lipid ingested. Surprisingly, hypoglycemia was not associated with a rise in these levels. As hypothyroidism strongly inhibits the lipolytic activity of catecholamines, this could be a consequence of depressed thyroid hormone levels (Wrutniak and Cabello, 1986).

In agreement with previous work (Bassett and Thorburn, 1969 ; Paisey and Nathanielsz, 1971 ; Nathanielsz et al., 1972), plasma cortisol levels decreased sharply after birth. Food restriction induced a rise until $8 \mathrm{~h}$ post partum ; Nightengale and Stott (1979) also observed a similar increase in newborn calves after delaying the first colostrum feeding. These changes might be a consequence of the hypoglycemia discussed above.

b) Changes in plasma TSH and iodothyronine levels. - The present results provide evidence that the thyroid function in newborn lambs is strongly affected by a 36-hour food restriction.

At birth spontaneous neonatal cooling stimulates TSH secretion in newborn lambs (Fisher et al., 1977) ; this agrees with the rise in plasma TSH levels observed in control lambs during the first $8 \mathrm{~h}$ of life. However, this increase did not occur in restricted animals. This might be explained by a change in the response of the hypothalamic-pituitary axis to spontaneous neonatal cooling ; in normal or obese men pituitary response to TRH is altered during fasting (Vinik et al., 1975 ; Carlson et al., 1977 ; Burman et al., 1979, 1980, 1983 ; Röjdmark and Nygren, 1983), but such data are not available in sheep. Therefore, although plasma total and free T4 levels rose during the first $8 \mathrm{~h}$ of life in control lambs, they did not change in restricted animals.

It is interesting that the magnitude of the neonatal rise in plasma T3 levels was similar in restricted and control lambs, despite the lack of TSH surge in the former animals. In agreement with the results of Sack et al. (1975), this suggests that the increase in plasma T3 levels was not a result of neonatal TSH hypersecretion. However, no convincing explanation has been reported and an hypothetical 5 '-deiodinase activation has not been proved yet.

After the rise in plasma T3 levels, plasma total and free T4 levels decreased in both groups of restricted lambs. The drop in plasma T3 levels was even more important : the value recorded at $16 \mathrm{~h}$ post partum was as low as $25 \%$ of that observed in suckling animals. These results are comparable with those obtained during a fasting period of $30 \mathrm{~h}$ to 10 days : in cattle, sheep and rats, plasma T4 and T3 levels decreased significantly (Blum et al., 1980 ; Tveit and Almlid, 1980 ; Blum and Kunz, 1981 ; Tveit and Larsen, 1983 ; Burger et al., 1981 ; Gavin and Moeller, 1983) ; in normal or obese men, only T3 was affected (Suda et al., 1978 ; Burman et al., 1979, 1980, 1983 ; Marugo et al., 1984). The particular sensitivity of T3 suggests that food restriction does not only affect thyroid secretion. A reduction of peripheral conversion of T4 to T3 has been reported in rats (Balsam and Ingbar, 1979 ; Chopra, 1980 ; Gavin et al., 1980 ; Balsam et al., 1981a, b ; Gavin and Moeller, 1983; Shank et al., 1984). The drop in the value of the 
T3/free T4 ratio recorded in our undernourished animals suggests that food restriction quickly induces the same phenomenon in newborn lambs.

In addition, when plasma T4 and T3 levels decreased sharply in restricted lambs ( 8 to $16 \mathrm{~h}$ post partum), plasma TSH levels did not change in those receiving colostrum alone, whereas they rose in lactose-supplemented animals. Therefore, the responsiveness of pituitary TSH secretion to thyroid hormone deficiency seems strongly dependent on caloric intake in newborn lambs. In fact, Rödjmark and Nygren (1983) have reported results suggesting that this "caloric " effect is mediated by glucose levels.

The increase in plasma reverse T3 levels during food restriction observed in the present work is comparable to results obtained during fasting in normal (Suda et al., 1978 ; Hughes et al., 1984) and obese (Burman et al., 1979, 1980 ; Jaedig and Faber, 1982 ; Marugo et al., 1984) men and in sheep (Blum et al., 1980). However, during fasting reverse T3 levels dot not change (Blum and Kunz, 1981) or decrease (Tveit and Almlid, 1980) in calves. A decreased metabolic clearance rate of reverse T3 (Suda et al., 1978 ; Blum and Kunz, 1981) and an enhanced peripheral conversion of T4 to reverse T3 (Suda et al., 1978) have been reported in men and rats. This agrees with the increase in the value of the reverse T3/free T4 ratio observed during food restriction in the present work.

The only effect of lactose supplementation in restricted lambs was to reduce the decrease in plasma total and free T4 levels as a consequence of the restoration of TSH response to low thyroid hormone levels. This limited influence probably can be explained by the weak effect on glycemia, an important factor in thyroid secretion and cell 5'-deiodination (Burger et al., 1980, 1981 ; Gavin and Moeller, 1983 ; Hughes et al., 1984).

\section{Refeeding.}

Twelve hours after the onset of ad libitum feeding and despite a complete restoration of glycemia, plasma cortisol levels remained slightly elevated in all restricted lambs ; by increasing the utilization of amino acids for neoglucogenesis, this hypercortisolemia could result in the persistance of high urea levels in these animals. The observation that plasma free fatty acid concentrations were only restored in lactose-supplemented lambs is not clear.

In contrast to plasma T4 levels, those of T3 were not restored $12 \mathrm{~h}$ after the onset of ad libitum feeding. This phenomenon also occurs in calves (Blum and Kunz, 1981 ; Tveit and Larsen, 1983) and in obese men (Burman et al., 1980). In rats, the restoration time of T3 after refeeding corresponds to the duration of the fasting period (Gavin and Moeller, 1983). As T4, the reverse T3 levels were normalized $12 \mathrm{~h}$ after ad libitum feeding in our restricted lambs.

In conclusion, food restriction in newborn lambs dramatically affects neonatal changes in plasma iodothyronine, TSH and cortisol levels. TSH and T4 secretion and T4 deiodination both seem altered by the nutritional status. 
Acknowledgements. - The authors wish to thank $M$. Thériez, Head of the Laboratory of Ovine Production where the animal experiments were conducted, Mrs. Christiane Foucher for her excellent technical assistance and NIADDK for the supply of oTSH RIA reagents (antisera and cold hormone).

Résumé. Effets d'une sous-nutrition sur les concentrations plasmatiques de cortisol, TSH et iodothyronine chez l'agneau nouveau-né.

Les effets d'une sous-nutrition effectuée de la naissance à $36 \mathrm{~h}$ post-partum sur la fonction thyroïdienne néonatale ont été étudiés chez l'agneau Limousin $x$ Romanov. Les animaux témoins $(n=18)$ pouvaient têter les mères à volonté, alors que les animaux restreints $(n=16)$ recevaient une quantité limitée de colostrum, en proportion du poids du corps ; 8 de ces derniers étaient supplémentés en lactose $(30 \mathrm{~g} / \mathrm{l}$ de colostrum).

Les taux plasmatiques de glucose et d'acides gras libres sont significativement plus faibles chez les agneaux restreints, alors que l'urémie est élevée. Les concentrations plasmatiques de cortisol diminuent pendant toute la période d'observation chez les animaux témoins, mais augmentent au cours des 8 premières heures de la vie chez les restreints. La supplémentation en lactose restaure seulement partiellement la glycémie et l'urémie.

La sous-nutrition induit des modifications importantes de la fonction thyroïdienne néonatale. L'élévation post-partum des taux plasmatiques de TSH, T4 et T4 libre qui survient chez les agneaux témoins est inhibée chez les restreints. Cependant, l'augmentation néonatale de la T3 n'est pas affectée, ce qui indique que cette évolution physiologique n'est pas dépendante de l'hypersécrétion de TSH. Les concentrations plasmatiques d'hormones thyroïdiennes diminuent ensuite de manière brutale au cours de la restriction alimentaire, alors que la triiodothyroninémie inverse devient supérieure à celle des animaux témoins. En réponse à l'effondrement des taux plasmatiques de T4 et de T3, la thyréostimulinémie s'élève uniquement chez les agneaux restreints supplémentés en lactose.

Les modifications considérables de la T3 et de la T3 inverse suggèrent que la sousnutrition altère la conversion périphérique de la T4 en T3 et en T3 inverse, en accord avec les modifications significatives de la valeur des rapports T3/T4 libre et T3 inverse/T4 libre.

Douze heures après le début de la période de réalimentation, les taux plasmatiques de T4 et de T3 inverse sont complètement normalisés, alors que la triiodothyroninémie reste déprimée.

En conclusion, la fonction thyroïdienne de l'agneau nouveau-né est fortement altérée par une restriction alimentaire, en terme de sécrétion et de conversion périphérique de la T4.

\section{References}

BALSAM A., INGBAR S. H., 1979. Observations on the factors that control the generation of triiodothyronine from thyroxine in rat liver and the nature of the defect induced by fasting. $J$. clin. Invest., 63, 1145-1156.

BALSAM A., SEXTON F., INGBAR S. H., 1981a. Effects of dietary manipulations on the in vitro generation of $3,5,3^{\prime}$-triiodothyronine from thyroxine in rat liver preparations. Life Sci., 28 , $1727-1736$.

BALSAM A., SEXTON F., INGBAR S. H., 1981b. The influence of fasting and the thyroid state on the activity of thyroxine $5^{\prime}$-monodeiodinase in rat liver : kinetic analysis of microsomal formation of triiodothyronine from thyroxine:- Endocrinology, 108, 472-477.

BASSETT J., THORBURN G., 1969. Fetal plasma corticosteroids and the initiation of parturition in sheep. J. Endocrinol., 44, 285-286.

BERGMEYER H. U., BERNT E., SCHMIDT F., STORK H., 1974. Glucose : determination with hexokinase and glucose-6-phosphate-dehydrogenase. In : Methods of enzymatic analysis. Vol. 3, Acad. Press, New York, 1196-1201. 
BLUM J. W., GINGINS M., VITINS P., BICKEL H., 1980. Thyroid hormone levels related to energy and nitrogen balance during weight loss and regain in adult sheep. Acta endocrinol., 93. 440-447.

BLUM J. W., KUNZ P., 1981. Effects of fasting on thyroid hormone levels and kinetics of reverse triiodothyronine in cattle. Acta endocrinol., 98, 234-239.

BURGER A. G., BERGER M., WIMPFHEIMER K., DANFORTH E., 1980. Interrelationships between energy metabolism and thyroid hormone metabolism during starvation in the rat. Acta endocrinol., 93, 322-331.

BURGER A. G., HUGHES J. N., SAVILLE E., 1981. Starvation and thyroid function : effects on thermogenesis and serum thyrotropin. Life Sci., 28, 1737-1744.

BURMAN K. D., DIMOND R. C., HARVEY G. S., O'BRIEN J. T., GEORGES L. P., BRUTON J., WRIGHT F. D., WARTOFSKY L., 1979. Glucose modulation of alterations in serum iodothyronine concentrations induced by fasting. Metabolism, 28, 291-299.

BURMAN K. D., SMALLRIDGE R. C., BURGE J. R., CARLSON D., WARTOFSKY L., 1983. Ipodate restores the fasting-induced decrement in thyrotropin secretion. J. clin. Endocr. Metab., 57, $597-602$.

BURMAN K. D., SMALLRIDGE R. C., OSBURNE R., DIMOND R. C., WHORTON N. E., KESLER P., WARTOFSKY L., 1980. Nature of supressed TSH secretion during undernutrition : effect of fasting and refeeding on TSH responses to prolonged TRH infusions. Metabolism. 29, 46-52.

CABELLO G., 1980. Relationships between thyroid function and pathology of the newborn calf. Biol. Neonate, 37, 80-87.

CABELLO G., 1983. Endocrine reactivity (T3, T4, cortisol) during cold exposure in pre-term and fullterm lambs. Biol. Neonate, 44, 224-233.

CABELLO G., LEVIEUX D., 1980. Neonatal changes in the concentrations of thyrotropin, triiodothyronine, thyroxine and cortisol in the plasma of preterm and full-term lambs. J. develop. Physiol., 2, 59-69.

CABELLO G., LEVIEUX D., 1981. Hormonal status in the newborn lamb (cortisol, T3, T4). Relationships to the birth weight and the length of gestation : effect of the litter size. Biol. Neonate, 39, 208-216.

CABELLO G., LEVIEUX D., GIRARDEAU J. P., 1984. Influence des hormones thyroïdiennes sur l'apparition des diarrhées néonatales. In : Coll. La diarrhée du jeune, CNRS-CNERNA, Publ. INSERM, 121, 61-72.

CABELLO G., LEVIEUX D., GIRARDEAU J. P., LEFAIVRE J., 1983. Intestinal K99+ Escherichia coli adhesion and absorption of colostral $\lg G_{1}$ in the newborn lamb : effect of fetal infusion of thyroid hormones. Res. vet. Sci., 35, 242-244.

CABELLO G., MICHEL M. C., 1974. Plasmatic hormonal iodine in healthy and diarrheic calves. Horm. Metab. Res., 6, 434.

CARLSON H. E., DRINICK E. J., CHOPRA I. J., HERSHMAN J. M., 1977. Alterations in basal and TRH-stimulated serum levels of thyrotropin, prolactin and thyroid hormones in starved obese men. J. clin. Endocr. Metab., 45, 707-713.

CHOPRA I. J., 1980. Alterations in monodeiodination of iodothyronines in the fasting rat : effects of reduced non protein sulfhydryl groups and hypothyroidism. Metabolism, 29, 161-167.

CUESTAS R. A., LINDALL A., ENGEL R. R., 1976. Low thyroid hormones and respiratory distress syndrome of the newborn. Studies on cord blood. New Engl. J. Med., 295, 297-302.

FISHER D. A., DUSSAULT J. H., SACK J., CHOPRA I. J., 1977. Ontogenesis of hypothalamicpituitary-thyroid function and metabolism in man, sheep and rat. Rec. Progr. Horm. Res., 33, 59-116

GAVIN L. A., McMAHON F. A., MOELLER M., 1980. Dietary modification of thyroxine deiodination in rat liver is not mediated by hepatic sulfhydryls. J. clin. Invest., 65, 943-946.

GAVIN L. A., MOELLER M., 1983. The mechanism of recovery of hepatic T4-5' -deiodinase during glucose-refeeding : role of glucagon and insulin. Metabolism, 32, 543-551.

GIRARD J., PINTADO E., FERRE P., 1979. Fuel metabolism in the mamalian fetus. Ann. Biol. anim. Biochim. Biophys., 19, 181-197.

HUGUES J. N., BURGER A., PEKARY A. E., HERSHMAN J. M., 1984. Rapid adaptations of serum thyrotrophin, triiodothyronine and reverse triiodothyronine levels to short-term starvation and refeeding. Acta endocrinol., 105, 194-199. 
JAEDIG S., FABER J., 1982. The effect of starvation and refeeding with oral versus intravenous glucose on serum 3,5-, 3,3' - and $3^{\prime}, 5^{\prime}$-diiodothyronine and $3^{\prime}$-monoiodothyronine. Acta endocrinol., 100, 388-392.

MARUGO M., BAGNASCO M., CONTESSINI M., BESSARIONE D., SCHENONE F., MIGNONE D., BERNASCONI D., MAZZOCCHI G., GIUSTI M., 1984. Variations of thyroid hormones during total fasting in obese and in obese diabetic subjects. J. endocr. Invest., 7, 197-200.

MELLOR D. J., PEARSON R. A., 1977. Some changes in the composition of blood during the first 24 hours after birth in normal and growth retarded lambs. Ann. Rech. vét., 8, 460-467.

MOORE J. J., SAX S. M., 1965. A revised automated procedure for urea nitrogen. Clin. chim. Acta, 11, 475-476.

NATHANIELSZ P. W., COMLINE R. S., SILVER M., PAISEY R. R., 1972. Cortisol metabolism in the fetal and neonatal sheep. J. Reprod. Fert., suppl. 16, 35-39.

NIGHTENGALE G. T., STOTT G. H., 1979. The effects of delayed feeding on serum cortisol concentration in neonatal calves. J. Dairy Sci., 62, 92-93.

PAISEY R. R., NATHANIELSZ P. W., 1971. Plasma cortisol levels in the newborn lamb from birth to 30 days. J. endocr., 50, 701-702.

REDDING R. A., PEREIRA C., 1974. Thyroid function in respiratory distress syndrome (R.D.S.) of the newborn. Pediatrics, 54, 423-428.

RÖJDMARK S., NYGREN A., 1983. Thyrotropin and prolactin responses to thyrotropin-releasing hormone : influence of fasting- and insulin-induced changes in glucose metabolism. Metabolism, 32, 1013-1018.

SACK J., BEAUDRY M., DELAMATER P. V., OH W., FISHER D. A., 1975. The mechanism of the T3 response to parturition. Pediatr. Res., 9, 682.

SHANK M. L., SINGH S. P., BLIVAISS B. B., KABIR M. A., WILLIAMS K., PREMACHANDRA B. N., 1984. Ethanol feeding and thyroid hormone monodeiodination. Metabolism, 33, 667-671.

SHUBBER A. H., DOXEY D. L., BLACK W. J. M., FITZSIMONS J., 1979. Colostrum production by ewes and the amounts ingested by lambs. Res. vet. Sci., 27, 280-282.

SUDA A. K., PITTMAN C. S., SHIMIZU T., CHAMBERS J. B., 1978. The production and metabolism of 3,5,3' -triiodothyronine and $3,3^{\prime} 5^{\prime}$-triiodothyronine in normal and fasting subjects. J. clin. Endocr. Metab., 47, 1311-1319.

TVEIT B., ALMLID T., 1980. T4 degradation rate and plasma levels of TSH and thyroid hormones in ten young bulls during feeding conditions and $48 \mathrm{~h}$ of starvation. Acta endocrinol., 93 , 435-439.

TVEIT B., LARSEN F., 1983. Suppression and stimulation of TSH and thyroid hormones in bulls during starvation and refeeding. Acta endocrinol., 103, 223-226.

VINIK A. I., KALK W. J., McLAREN H., HENDRIKS S., PRIMSTONE B. L., 1975. Fasting blunts the TSH response to synthetic thyrotrophin-releasing hormone (TRH). J. clin. Endocr. Metab., 40, 509-511.

WRUTNIAK C., 1985. Mise en évidence d'anomalies de la fonction thyrö̈dienne néonatale chez l'agneau hypotropique. Origine et conséquences physiologiques. Thèse de $3^{\text {e }}$ cycle, Univ. Clermont-Ferrand (France), $98 \mathrm{p}$.

WRUTNIAK C., CABELLO G., 1985. Endocrine activity in preterm and full-term lambs. 1. Adrenal response to synacthen. 2. Thyroid response to ovine TSH or TRH. Biol. Neonate, 47, 280-287.

WRUTNIAK C., CABELLO G., 1986. Influence of hypothyroidism on the lipolytic activity of norepinephrine in the newborn lamb. J. Endocr., 108, 451-454.

WRUTNIAK C., CABELLO G., BOSC M., 1985. Plasma free and total iodothyronines levels in hypophysectomized and intact lamb foetuses during the last third of gestation. Acta endocrinol., $110,388-394$. 